\title{
Board Effectiveness in International Financial Institutions: A Comparative Perspective on the Effectiveness Drivers in Constituency Boards
}

\author{
Stilpon Nestor*
}

\begin{abstract}
Using comparative data from a peer group of international and private financial institutions, this chapter explores what drives effectiveness in International Financial Institution (IFI) boards. It starts by identifying their overarching constituency nature and the dual role of directors as representative of shareholder governments and "fiduciaries" of the institution. It also underlines their somewhat contradictory power structure, with a high concentration of decision-making at board level, performed by non-professionals, whose nomination as "executives" belies the absence of any personal executive responsibilities in the organization even when these directors are full-time "residents" - another particularity of IFI boards. The main argument of the chapter is that, while these particularities are important, IFI boards resemble all other boards, especially those of private financial institutions, when it comes to the key drivers of their performance. These consists of their size, composition, leadership, diversity; the competencies and tenure of their directors; the quality of the support they get from management and the tools they use to maintain their effectiveness over time. The chapter concludes with some preliminary ideas on improving IFI board effectiveness.
\end{abstract}

\footnotetext{
* Stilpon Nestor, LL.M (Harv.), is the Managing Director, Nestor Advisors Ltd. and the Chairman of AKTIS Ltd. He has advised the boards of numerous private financial institutions as well as international financial institutions and organizations on governance issues. From 2010 to 2014 he sat on the board of the European Investment Bank. In the earlier part of his career he was the head of the oEcD's corporate Affairs division. E-mail address: snestor@ nestoradvisors.com. The author would like to thank Konstantina Tsilipira, Analyst at Nestor Advisors, and Lisa Andersson, Senior Analyst at AKTIS for their research support. My gratitude also goes also to Emmanuel Maurice, Enery Quinones and George Papakonstantinou, all senior advisors at Nestor Advisors, for their extremely valuable comments and insights.
} 


\section{Introduction}

The focus of this paper is the effectiveness of the boards of International Financial Institutions (IFIs). Its perspective is that of a practitioner.

Underpinning the discussion of IFI board effectiveness are two sets of elements: Firstly, the idiosyncratic nature of IFI boards, mostly due to their overarching constituency nature, which is addressed in Part 2 of the paper. Second, the key drivers of effectiveness of any board — that is, of any team that is supposed to direct and control an organization, as per Sir Adrian Cadbury's definition of governance. ${ }^{1}$

The analysis of the drivers, i.e., of the second element, is often based on comparisons between IFI and private Financial Institutions (FIs). The empirical research quoted throughout this chapter focuses on two different peer groups: a selected group of 11 large global and regional IFIs, analyzed internally at Nestor Advisors, ${ }^{2}$ and data from private banks collected and analyzed by AKTIS a company that specializes in bank governance data. ${ }^{3}$ This paper uses AKTIS governance data pertaining to the 25 largest European commercial banks. In some noted instances the data used pertain to the 24 globally significant banks (G-SIBs), not including Chinese banks.

\section{The Idiosyncrasy of IFIs and its Impact on Board Effectiveness}

\subsection{Constituency Boards}

At the heart of this discussion, and common to all IFIs, is what is often referred to as "a constituency board." This is a board in which directors are not appointed as individual "fiduciaries" of all shareholders/members; rather they are representatives of a "constituency," i.e., a single shareholder/stakeholder or of a group of them. The difference to the typical board as anticipated by company laws throughout the world, centers on the loyalty of board members, both as a psychological attribute and as an actual duty. Under most company laws, the members of the board are not there to serve the interest of the shareholders

1 "Corporate Governance is the system by which companies are directed and controlled." Committee on the Financial Aspects of Corporate Governance, The Code of Best Practice on Corporate Governance 6 (Gee 1992).

2 The data date from end-August 2017.

3 Stilpon Nestor and Lisa Andersson, "Ten Years on: Governance of the 25 largest European Banks a Decade After the Crisis" (AKTIS and Nestor Advisors, 2018) (forthcoming). The data date from end-2016. 
that helped elect them but those of the company as a whole. In the US, the duty is a "fiduciary" one to the shareholders but courts interpret this to be to the shareholders, not to a current shareholder. ${ }^{4}$ While there might be the occasional shareholder representative on an FI board, current practice and, most importantly, regulatory requirements and supervisory expectations make this a rare occurrence. ${ }^{5}$

In contrast, all IFI boards are constituency boards and their members have a "dual role": all members are shareholder representatives by design, ${ }^{6}$ with the exception of some individual independent experts. ${ }^{7}$ On the other hand, most IFIs explicitly postulate a duty of loyalty to the institution. For instance, the Code of Conduct for World Bank Board officials provides that "Board Officials shall hold the interests of the Organizations paramount..." while the Eг of Conduct states that "in discharging their duties to the Bank, members of the Board of Directors shall...endeavor to only act in the interest of the Bank...."

The loyalty tension in such boards is palpable, almost schizophrenic: member country representatives, usually civil servants who are legally bound to serve the interests of their country, are also expected to somehow transcend these interests and act in the interests of the organization as a whole. It is of course easy to hide behind "what is good for my country is good for the world." But this is hardly defendable when, for example, a director finds themselves in a minority of one in important matter that affects their country. Or comes in possession of important, confidential but not yet distributed documents that affect the interests of their country.

The IFI board thus looks much more like a general meeting of shareholders, a place where the synthesis of shareholder interests is to be negotiated rather than assumed. One would think that the Boards of Governors, the higher instance of shareholder decision making in most IFIs, should be playing this

4 Robert Clark, Corporate Law (Textbook Treatise Series) (2nd edn, AA Balkema 1986).

5 European Parliament and Council Directive 2013/36/EU on access to the activity of credit institutions and the prudential supervision of credit institutions and investment firms, amending Directive 2002/87/EC and repealing Directives 2006/48/EC and 2006/49/EC [2013] OJ L176/338 (Capital Requirements Directive 2013) art 88 2 b.

6 The dual role might be less pronounced for directors who represent multi-country constituencies. In some organizations, there exist internal constituency arrangements to address divergence of opinion among constituency members in determining the constituency position.

7 In some cases, there may be a relatively small number of directors appointed by all shareholders due to their expertise in the matters dealt with by the board. The board of EIB includes 6 such directors. European Investment Bank, EIB Group Corporate Governance Report 2016 (EIB 2016) <www.eib.org/attachments/general/reports/eib_group_corporate_gover nance_report_2016_en.pdf $>$ accessed 24 January 2018. 
synthesizing role given their stature and seniority of the Governors, usually Ministers in their respective countries. In practice, it works the other way around. The IFI boards spend a lot of time negotiating the common denominators on strategy and governance from the perspective of individual constituencies and prepare the formal statements endorsed by governors; 8 instead of focusing on directing and controlling the institution, as per Sir Adrian's definition.

\section{2 $\quad$ Board Effectiveness}

What is an effective board? The answer is deceptively simple: an effective board is one that is composed, organized and functions in a way that optimizes the delivery of its mandate. Note that this discussion is not about the effectiveness of the organization but of its board. There is an obvious relationship between the two, but they are not the same. The effectiveness of the organization will be linked to optimizing governance. Optimal governance will depend on the effectiveness of the board but also on the adequate distribution of responsibility and authority in the organization, i.e., the mandate and power of various principals and agents ${ }^{9}$-including, most importantly, the mandate and retained powers of the board.

This chapter does not focus on the discussion of the board's mandate as such. However, it is important to note that IFI boards do have significantly different mandates than private sector FIs. The most important difference consists in the vastly more expansive authorities that IFI boards retain compared to their commercial counterparts that tend to delegate much more to professional management. ${ }^{10}$ Despite a post crisis push by regulators for bank boards to assume more direct responsibility in certain areas, private FI mandates still cannot be compared to those of most IFI boards. The latter typically retain most credit/financial decision-making authority, ${ }^{11}$ a function that has been delegated to management credit committees a long time ago. ${ }^{12}$ This has an important impact on the agendas of IFI boards that are disproportionately tilted towards operational decision making. This constraint seems even more counterproductive if one takes into consideration the profile of the large majority of

8 High-Level Commission on Modernization of World Bank Group Governance, Repowering the World Bank for the 21st Century (2009) 22.

9 Michael Jensen and William Meckling, "Theory of the Firm: Managerial Behaviour, Agency Costs and Ownership Structure" (1976) 3 J. Financial Econ 305, 309.

10 Domenico Lombardi, "The Governance of the World Bank: Lessons from the Corporate Sector" (2008) 3 Rev Int Organ 5 .

11 For example, this is the case in the WвG, the евRD and the егв.

12 In a few cases, private FI boards retain credit authority for very large credit transactions. 


\section{Resident/ Number of \\ Non-Resident Meetings}

1 International Bank for Reconstruc- Yes

$>$ Twice/week tion and Development (IBRD)

2 International Monetary Fund (IMF) Yes

3 European Investment Bank (EIB) No

Several times/week

4 European Bank for Reconstruction Yes $10 /$ year and Development (EBRD)

5 International Fund for Agricultural No Development (IFAD)

6 Black Sea Trade and Development No $2-3 /$ month Bank (BSTD B)

7 Asian Development Bank (ADB) Yes

3/ year

$\mathrm{N} / \mathrm{D}$

Several times/ month

8 Asian Infrastructure Investment No $5 /$ year Bank (AIIB)

9 African Development Bank (AfDB) Yes As often as required

10 Inter-American Development Bank Yes Group (IADB)

11 Nordic Investment Bank (NIB) No 8 / year

IFI board members: civil servants with limited financial experience-a point this article will return to.

Extensive retained authorities explain, at least partly, one more IFI characteristic: a significant majority of them are run by resident boards who meet much more often than private FI boards. Table 1.1 identifies the boards that are resident and compares the frequency of board meeting among the IFI peer group.

What is interesting in the typical IFI board is that while the directors are "executive"13 in the sense that they are full time and partake in extensive collective board authorities, none of them have individual executive responsibilities in the running of the institution, as is usually the case in private FI

13 In many IFIs, like IBRD, IMF, IADB, AfDB, their actual title is "executive director." 
management boards — the lower tier in a two-tier board system ${ }^{14}$ —or among executive directors in one tier systems. Their personal responsibility resembles those of Non-Executive Directors ("NEDs") in one-tier systems or supervisory board directors in two-tier ones. Just like in the case of NEDs, their accountability for adequately discharging their responsibilities is collective, not individual. ${ }^{15}$ Moreover, this extensive authority is of an ambiguous nature as identified in the Zedillo committee's report on World Bank governance, which I believe speaks to the issue in many IFI boards:

The division of labor between Board and Management in the WBG is ambiguous. In some instances, disputes emerge over whether a decision is Management's to recommend and the Board's to approve or turn down, or whether it falls under the Board's prerogative to direct the President. This ambiguity makes it difficult to ascertain who is responsible and who should be held accountable. ${ }^{16}$

In contrast to their extensive transactional authority, IFI boards seem to have little say in the appointment of the top teams in the institutions they lead. The executive leader (i.e., president, managing director, etc.) of the institution is usually appointed by the shareholders (usually, the Governors), typically in a quite non-transparent way. In the case of EIB, a management board is appointed directly by the Governors, on a constituency basis. In many IFIs, the top team around the institution's leader is appointed by him/herself with only information provided to the board on such appointments. ${ }^{17}$ This contrast sharply with private FI practice, where the board and its nomination committee would be closely associated with all top management hiring

14 In a one-tier board structure, both supervisory and managerial duties are discharged by a unified board of directors. In contrast, a two-tier board structure consists of a management board and a supervisory board that both act on an autonomous basis; the management board comprises senior management while the supervisory board consists of non-executive members, that have different responsibilities and tasks. David Kershaw, Company Law in Context: Text and Materials (OUP 2012) 216.

15 This refers to governance accountability rather than personal liability of a criminal or civil nature, a related but quite distinct subject which is not be discussed in this paper. For a comprehensive review of liability regimes in private companies in Europe see Carsten Gerner-Beuerle and others, "Study on Directors' Duties and Liability" (2013) LSE Enterprise <http://ec.europa.eu/internal_market/company/docs/board/2013-study-analysis _en.pdf $>$ accessed 22 December 2017.

16 Committee on the Financial Aspects of Corporate Governance (n 2) 13.

17 Lombardi (n 11$) 18$. 
decisions and would be well informed on the performance of the senior executive team. ${ }^{18}$

\section{The Individual Drivers of Effectiveness}

Based on years of working with boards, I would distinguish nine individual drivers of board effectiveness that are relevant to all organizations:
A. Size of the board.
B. Board leadership.
C. Knowledge, skills and experience of board members.
D. Board diversity.
E. Tenure of board members.
F. Personal commitment of board members.
G. Board workload and its distribution through committees.
H. Board "maintenance."
I. Board support.

It is also important to note that these board drivers can be categorized under two broad headings: people-related and structure-related — and some belong to both categories. In general, IFI boards are much more about structure than other organizations, especially as compared to commercial boards. The reason is simple: given the constituency nature of these boards, appointments are completely shareholder-driven — and there are many shareholders. Unlike private FIs, IF I boards have practically no say on the profile and quality of their members. They have no mandate to control them for fit and proper aspects that are now a litmus test for board membership in the private sector. ${ }^{19}$ On the other hand, IFI boards usually have more elaborate rules on (weighted) voting, on the board's formal authorities, and on the ways boards connect and get information from management. Usually they also have a fairly developed committee structure, although committees are staffed less on the basis of expertise and more on representation imperatives. Such imperatives also explain the fact that, in contrast to private FIs, in almost all IFIs committee attendance is often open to all board members. ${ }^{20}$

18 All the banks of our private FI (European) peer group appoint all top management at executive committee level. Nestor and Andersson (n 3 ) 19.

19 See below page 10.

20 An exception is the non-resident board of the EIв that restricts committee attendance to committee members only. Also, Ethics committees in several IFIs have more restrictive attendance rules given the sensitivity of the issues in their purview. 
Another important point to note is that there is always a degree of tension among the different effectiveness drivers. For example, consider diversity: a degree of diversity is very welcome as it allows for out-of-the-box thinking; but too much diversity might compete at the margin with director knowledge, skills and experience (KSE). Workload is another example: while boards need to work harder as they have more and more responsibilities and tasks in the eyes of supervisors and other stakeholders, an overly heavy workload might result in boards becoming rubber stamping machines, thus lowering effectiveness. We are, as ever, looking for the golden middle.

\subsection{The Size of the Board}

Clearly size impacts effectiveness because it impacts the dynamics of board discussions: ${ }^{21}$ too small a board limits perspective and might amplify group think. But too large a board inhibits discussion and thereby limits challenge. Is there a "magic" number? Our experience suggests that there is significant pressure by supervisors for private FIs with larger boards to bring them down to anywhere between $13^{-15}$ members. Hence the average size in our private FI peer group is currently approximately 14 , down from approximately 16 in $2007 .^{22}$

IFIs have much larger boards, as per Table 1.2. The mean among our 11 IFI peers is approximately 18 members. Furthermore, this relatively high number significantly underestimates the number of people in the board room-and hence the negative impact on board dynamics. In most IFIs, board meetings always include senior management (which is also the case in many private FIs) and, usually, many alternate directors as well as board advisors. ${ }^{23}$

It might be that limiting the number of people in the room even without lowering the number of seats might actually play a positive role in board dynamics. This might not be possible in all, even most, board meetings. But it is important that, from time to time, the board has the opportunity to meet without all the other attendees. Limiting the right to take the floor to directors only might also help. Finally, some IFI boards ${ }^{24}$ have adopted rules that limit the time available to participants for oral interventions while others ${ }^{25}$ encourage directors to prepare written statements on agenda issues and look down

\footnotetext{
21 Colin Carter and J. William Lorsch, Back to the Drawing Board:Designing Corporate Boards for a Complex World (HBSP 2003) 88.

22 Nestor and Andersson (n 3$) 4$.

23 For example, the WBG has 24 alternate EDs in addition to its 25 EDs, the EIB 19 alternate directors in addition to its 29 EDs and the EBRD 23 alternate EDs in addition to its 23 EDs.

24 For example, the World bank.

25 For example, the IMF.
} 


\begin{tabular}{lll}
\hline & IFI & Board Size \\
\hline 1 & IBRD & 25 \\
2 & IMF & 24 \\
3 & EIB & 29 \\
4 & EBRD & 23 \\
5 & IFAD & 18 \\
6 & BSTDB & 11 \\
7 & ADB & 12 \\
8 & AIIB & 12 \\
9 & AfDB & 20 \\
10 & IADB & 14 \\
11 & NIB & 8 \\
& Average & $\mathbf{1 7 \cdot 9}$ \\
\hline
\end{tabular}

on "read" statements during board minutes. The results on board effectiveness seem to be rather mixed from such limitations.

\subsection{Board Leadership}

Every team needs a leader and the quality of the leader clearly impacts both on the capacity of the team to deliver on its mandate as well as on the culture that drives team dynamics. When it comes to boards, the quality of the leader impacts directly on the quality and openness of the discussion and therefore the robustness of challenge it offers to management. As Sir Adrian Cadbury highlighted, "The job of the chairman is to encourage board members to give of their individual best in a cooperative cause."26

On the issue of board leadership things could not be more different between private FIs and IFIs. In the latter, the leader of the board is almost always the leader of the institution. ${ }^{27}$ In corporate governance terms, we always have a Chairman/CEO. In contrast, the great majority of G-SIBs (more than 80 percent) have now separated the position of the Chairman of the Board from that of the CEO. ${ }^{28}$ The rationale is obvious: the leader of the team whose main

\footnotetext{
26 Adrian Cadbury, Corporate Governance and Chairmanship: A Personal View (oup 2002) 79.

27 In our IFI peer group, only Nı has a board chairman that is non-executive and is a different person than the $\mathrm{CEO} /$ president of the organization.

28 Nestor and Andersson (n 3$) 6$.
} 
purpose is to challenge the executive leadership and hold it accountable cannot be a member of management. In Europe, this is now a regulatory requirement for banks. ${ }^{29}$

Another important difference is that the IF I President, unlike the CEO or the Chairman in private FIs, is usually appointed by the shareholders. As per Table 1.3, in eight out of 11 IFI the head of the organization is appointed by the board of governors (usually the ministers of finance of the member countries). This is not necessarily a negative factor, given the level of power that is concentrated in the hands of the executive head in most IFIs in terms of running the organization - but not in terms of transactional decision making, as discussed above.

But even in IFIs where the board of directors is responsible for the appointment of the organization's head (such as the World Bank or the IMF), the appointment is rarely characterized by the relatively orderly and (internally) transparent process that prevails among best practice private FIs, run by the nomination committee of the board. Moreover, if when they are appointed by the board, there seems to be little accountability of the President to the board as such. For example, there is little evidence of a robust performance evaluation framework for the President in most of the IFIs surveyed and what exists seems to be of a rather "soft" nature. In short, one can reasonably conclude that the board is not a "sovereign" decision maker when it comes to appointing and monitoring the performance of its leader, and that its role is only a "front" for behind the scenes shareholder wrangling.

The tenure of an organization's leader is another important element of leadership effectiveness. An entrenched leader will tend to be less effective and more set in their ways. In this respect, our two peer groups seem to be on the same wavelength. Private FI peers have an average CEO tenure of 3.8 years, which is not very dissimilar to the IF I average President average tenure of 5.1 years.

When the Chairman is also the CEO, private companies will appoint a leader among the non-executive population that can step in when the Chairman/CEO is conflicted. The title varies in different jurisdictions-senior or lead independent director, independent vice chairmen — but the function is roughly the same. The way that the IFIs have sought to address the same potential conflicts is though the position of the "dean," ${ }^{30}$ the senior member among the

29 Capital Requirements Directive 2013 (n 5 ) art 88.1.e.

30 For example, both the IBRD and the EBRD boards have deans. Senior non-management directors are given specific functions even in IFIs that do not have the specific practice of appointing a dean (e.g., the EIB). 


\begin{tabular}{|c|c|c|c|c|c|}
\hline & IF I & $\begin{array}{l}\text { Board } \\
\text { Role }\end{array}$ & $\begin{array}{l}\text { Executive } \\
\text { Role }\end{array}$ & $\begin{array}{l}\text { Appointment } \\
\text { by: }\end{array}$ & $\begin{array}{l}\text { Tenure in Years of } \\
\text { current President }\end{array}$ \\
\hline 1 & IBRD & Chairman & President & BoD & 6 \\
\hline 2 & IMF & Chairman & $\begin{array}{l}\text { Managing } \\
\text { Director }\end{array}$ & BoD & 6.5 \\
\hline 3 & EIB & Chairman & President & BoG & $\begin{array}{l}\qquad 6 \\
\text { (re-appointed for } \\
\text { another six-year term, } \\
\text { starting on the first of } \\
\text { January 2018) }\end{array}$ \\
\hline 4 & EBRD & Chairman & President & BoG & $\begin{array}{c}6 \\
\text { (re-elected for a second } \\
\text { four-year term in 2016) }\end{array}$ \\
\hline 5 & IFAD & Chairman & CEO & BoG & 1 \\
\hline 6 & BSTDB & Chairman & CEO & BoG & $3 \cdot 5$ \\
\hline 7 & $\mathrm{ADB}$ & Chairman & President & BoG & 5 \\
\hline 8 & AIIB & Chairman & President & BoG & 2 \\
\hline 9 & AfDB & Chairman & $\begin{array}{l}\text { CEO / } \\
\text { President }\end{array}$ & BoG & 2.5 \\
\hline 10 & IADB & Chairman & $\begin{array}{l}\text { CEO / } \\
\text { President }\end{array}$ & BoG & 12.5 \\
\hline 11 & NIB & - & $\begin{array}{l}\text { CEO / } \\
\text { President }\end{array}$ & BoD & $5 \cdot 5$ \\
\hline
\end{tabular}

non-management directors. The dean often assumes responsibilities related to the board's effectiveness and is the point of reference among non-management directors on issues that might be awkward for the President to address. In addition, it is a way to invest some authority in one among few directors that embody some institutional memory. ${ }^{31}$

\subsection{Knowledge, Skills and Experience (KSE) of Board Members}

It is an obvious point - the most obvious among the "people" drivers- that the effectiveness of a board is related to the knowledge, skills and experience of its members. And yet, lack of KSE was one of the key corporate governance

31 See discussion in subsection (e). 
failings in the run up to the 2007-2008 financial crisis. ${ }^{32}$ In the Lehman Brothers board, we had a NED population that included actresses, theater producers, but no bankers until early 2008 ! That is why post crisis regulation not only put the KSE of directors at the heart of supervisory expectations and controls; ${ }^{33}$ as discussed, it also made it the explicit job of the board to ensure that there is adequate KSE on the board-some would say in direct contradiction to the "spirit" of company law in many (mostly European) jurisdictions which reserve decisions related to the composition of the board to the shareholders. Significant institutions are expected to have nomination committees that ensure that NEDs are not only "independent," but also have the demanding KSE that is required for the governance of such complex organizations. ${ }^{34}$ While the appointment (usually informal) of some directors by certain shareholders was and still is not completely uncommon, significant FIs are expected to have "independent instances" in which such appointments are vetted - and sometimes refused. FIs ignore such best practice at their peril—for example, during the last few years it has not been uncommon among ЕСв-supervised banks to have the Single Supervisory Mechanism rigorously challenge director appointments.

While some IFI charters provide that board members should "be persons of high competence in economic and financial matters" (EBRD), getting the right level of KSE is quite problematic in constituency boards, and much more so in IFIs. Because of the representative nature of directorships, IFI boards have rarely the tools to "raise the bar" when it comes to the quality of individual directors. In most cases, the latter are not, in practice "elected" as in private organizations but appointed by individual shareholders. ${ }^{35}$ It is therefore not a

32 Catherine Lawton and Stilpon Nestor, "Bank Board after the Flood: The Changing Governance of the 25 Largest European Banks" (Nestor Advisors Ltd 2010) 62, 63 .

33 For example, the PRA/FCA in the UK establishes clear responsibility in vetting the competences and specific expertise of officers at various positions. Supervisory Statement of the Prudential Regulation Authority on Strengthening Individual Accountability in Banking (2017) SS28/15 28.

34 For example, in Europe the European Banking Authority requires banks to ensure that such tests are performed by the nomination committee of the board. When performing suitability evaluations, institutions shall examine skills like authenticity, language, decisiveness, communication, judgement, customer and quality-oriented, leadership, loyalty, external awareness, negotiating, persuasive, teamwork, strategic acumen, stress resistance, sense of responsibility, chairing meetings. European Securities and Markets Authorities and European Banking Authority, "Final Report on Guidelines on the Assessment of the Suitability of Members of the Management Body and Key Function Holders Under Directive 2013/36/EU and Directive 2014/65/EU" (2017) EBA/GL/2017/12.

35 In at least one IFI Board (IFAD) the KSE issue may be compounded by the fact that it is the member State, not an individual, who is elected as Board member. This gives member 
surprise to find that directors with banking experience constitute only around 25 percent of the board population in our IFI peer group, on average. In comparison, in the boards of our private FI (European) peer group 44 percent of members have recent FI experience. Nevertheless, the IFI average number is not too far from that for the US top 25 banks at 26 percent. ${ }^{36}$ Moreover, some IFI boards pack an impressive FI expertise: more than 50 percent of IMF board members have recent financial sector expertise. This might be an important underlying factor in the quality of IMF board discussions-something many knowledgeable observers have signaled to us during various engagements.

One obvious way to address the issue of suboptimal KSE is to create a board committee with responsibilities and mandate that resemble that of nomination committees in private FI boards. ${ }^{37}$ But calls for such a vetting process have not attracted much support among IFI shareholders as they take too much power away from them - the sovereign deciders who appoint individual members in most IFIS. IFI boards have tried to address this KSE gap by providing ad hoc training or "technical briefings" for board members. The problem is that the training is limited in time and scope and often focuses on a specific issue that arises in the context of a problematical transaction that is before the board for approval. As such, the training cannot adequately raise the overall KSE level of individual members.

A "hard wired" nomination committee and policy in IFIs might fit the bill but unless a wholesale reform of board appointment processes could magically materialize there seems to be limited space for this. However, there might be space for a less constrictive, "soft" approach in which a committee of the board with governance responsibilities would maintain a profile matrix of competencies required to make board composition optimal. This body would regularly report on gaps between actual and desired board composition to the governors as they engage in director selection. A similar approach has recently been adopted by вгв in the appointment of its Management Committee, its full time executive directors appointed by the shareholders of the Bank. This body does not have power to nominate but as advisory body it can point to the needs of the board in terms of KSE or diversity. ${ }^{38}$

Another, less intrusive way to address the lack of levers to promote KSE (and diversity), and to also introduce some out-of-the-box, challenging thinking is

States latitude to designate multiple representatives, with mostly negative effects in board cohesiveness and dynamics.

$36 \quad$ Nestor and Andersson (n 3$) 9$.

37 The Zedillo Committee on wвG reform proposed something similar to this. Committee on the Financial Aspects of Corporate Governance (n 2 ) 42.

38 European Investment Bank (n 6) 9. 


\begin{tabular}{llcc}
\hline & IFI & $\begin{array}{l}\text { Resident } \\
\text { Board }\end{array}$ & $\begin{array}{l}\text { Non-Resident } \\
\text { Board }\end{array}$ \\
\hline 1 & IBRD & $\checkmark$ & \\
2 & IMF & $\checkmark$ & $\checkmark$ \\
3 & EIB & & \\
4 & EBRD & $\checkmark$ & $\checkmark$ \\
5 & IFAD & & $\checkmark$ \\
6 & BSTDB & & $\checkmark$ \\
7 & ADB & $\checkmark$ & \\
8 & AIIB & & \\
9 & AfDB & $\checkmark$ & $\checkmark$ \\
10 & IADB & $\checkmark$ & \\
11 & NIB & & \\
\hline
\end{tabular}

to appoint members that are not shareholder representatives. There are only a few IFIs that allow non-shareholder representatives to be full participants at board meetings, albeit in an advisory, non-voting capacity. ${ }^{39}$ The experience is that these advisory directors are an important, positive factor in board deliberations in that they help the interests and voices of various shareholders around the table to converge and to emerge as the view of the institution. This approach is highly recommended for boards that are non-resident (see Table 1.1). But it would be hard to transpose it as such to resident boards given their workload-few independent experts could accommodate bi-weekly meetings. For the latter, other mechanisms for injecting non-partisan objectivity that is independent from management might need to be identified, such as advisory panels that meet with the board from time to time.

Finally, when it comes to skills in the risk and internal control area, mention should be made of partly or wholly independent audit committees which are composed not of members of the board but of experts who report to the

39 For example, at EIB the Board of Directors can co-opt up to six experts, so as to expand the Directors' professional expertise in specific areas. These experts, who are three Directors and three Alternate Directors, have an advisory role during the Board meetings, without any voting right. European Investment Bank, "Board of Directors" <http://www.eib .org/about/governance-and-structure/statutorybodies/board_of_directors/index.htm> accessed 29 December 2017. 
governors. ${ }^{40}$ In a nutshell, these arrangements might yield positive results if the work of the committee is closely coordinated with and adequately informs the work of the board.

\subsection{Diversity}

Diversity is now recognized as a key driver of effectiveness. ${ }^{41}$ It allows multiple perspectives on specific matters at hand and enhances the capacity of an organization to serve multiple stakeholders. Arguably, it is even more important in IFIs than in private FIs, precisely because the stakeholder universe is broader and more diverse than in private FIs.

When it comes to IFIs one needs not of course look at national (and, to a degree, ethnic) diversity. These are, by definition, present, given IF Is' intrinsically international character and representative boards.

But when it comes to gender diversity the picture is gloomy, especially when compared to private FIs. In our IF I peer group, the median of female participation in our 11-member peer group is approximately 18 percent - the outlier is the NIB with $5^{\circ}$ percent women. In contrast, the average for our private FI peer group is approximately 35 percent in 2016 , a significant difference. ${ }^{42}$

TABLE 1.5

IFI Women on Board

\begin{tabular}{lc} 
IBRD & $24 \%$ \\
IMF & $8.7 \%$ \\
EIB & $28.5 \%$ \\
EBRD & $13 \%$ \\
IFAD & $\mathrm{N} / \mathrm{D}$ \\
BSTDB & $36.3 \%$ \\
ADB & $8.3 \%$ \\
AIIB & $0 \%$ \\
AfDB & $22.2 \%$ \\
IADB & $21.4 \%$ \\
NIB & $50 \%$ \\
Average & $\mathbf{2 1 . 2 4} \%$ \\
\hline
\end{tabular}

40 For example, the вгв, the Iмғ and the Агів have such independent Audit Committees.

41 Hisham Farag and Chris Mallin, "Board diversity and financial fragility: Evidence from European banks” (2017) 49 IRFA 98.

42 Nestor and Andersson (n 3 ) 3. 
The reason for this suboptimal performance is the same as in the KSE case: the lack of a mechanism to control the profile of appointees. And the solutions are the same: injection of "outside," non-constituency objectivity and independence in the board composition; and broadening of the board's profile.

\subsection{Tenure}

In complex organizations, tenure-the number of years directors spend on board - is an important factor of effectiveness: if directors stay on the board too long their capacity to challenge diminishes and boards become "stale." The Lehman board offers again a good negative benchmark: 60 percent of directors were on the board for over 12 years in 2008. In contrast, in 2016 top 25 European FI boards had an average tenure of 5.3 years while in the top five US boards tenure reached 7.7 years. ${ }^{43}$

In contrast to private FIs, the problem in IFIs is not that boards are "stale" but that they never ripen to full maturity: tenure is not too long, it is too short. These are complex organizations, often much more complex than "plain vanilla" commercial banks that require sophisticated credit risk management, often at maturities far longer than the private sector. Individual directors need time to understand the institution before they reach, so to speak, "peak" value as board members, in terms of their capacity to contribute to strategy, to control and challenge management and to understand the substance of the myriad decisions they are making. Also, boards need to maintain an adequate level of institutional memory ${ }^{44}$ to properly direct the culture of the institution.

In view of these considerations, IF I tenure levels seem to be problematic. As evidenced in Table 1.6, among our 11 peers the average tenure barely reaches 2.5 years, less than half than that of private FIs.

Clearly, the "dual role" of directors discussed above is at the core of the tenure problem. As member country representatives, directors usually are civil servants and their appointments are at the mercy of political changes or simple mobility imperatives - the importance of their contribution as IFI board members takes a back seat.

\subsection{Personal Commitment of Board Members}

A common ailment among IFI boards is the personal engagement of board members in the functioning of the board. In some boards, it is not uncommon

43 Ibid 5 .

44 Stilpon Nestor, "Avoiding Pitfalls in the New Bank Governance Framework" The Banker (London, 28 July 2010). 


\begin{tabular}{llc}
\hline & IFI & $\begin{array}{c}\text { Average Tenure of current } \\
\text { executive directors (in years) }\end{array}$ \\
\hline 1 & IBRD & 1.98 \\
2 & IMF & 2.8 \\
3 & EIB & 2.9 \\
4 & EBRD & 2.2 \\
5 & IFAD & N/D \\
6 & BSTDB & 4.1 \\
7 & ADB & 1.22 \\
8 & AIIB & - \\
9 & AfDB & 2.28 \\
10 & IADB & 1.6 \\
11 & NIB & 4.3 \\
& Average & 2.59 \\
\hline
\end{tabular}

for directors to be absent from meetings and for "alternates" or counsellors to take their place. Even when the member of the board is a regular attendee, they are often more the head of an official delegation than an engaged individual board member. But well-functioning boards require engaged individuals much more than constituency spokesmen. As already noted in discussing tenure, the frequent change of faces at the table and the multiple voices behind one chair have a negative effect on board dynamics. Team cohesion suffers and "live" institutional memory is low. There is little personal responsibility invested and the discharge of director duties looks less like leadership and more like just a civil service job. In this respect, it might be useful if IF Is insisted more on personal attendance in boards and committees and limited the possibilities for substitution of the directors by alternates or other participants.

\subsection{Director Workload and Board Committees}

This is an area where comparisons between IFIs and private FIs are rather meaningless given the vastly broader mandate of IFIs in deciding operational matters. It is especially so for those IFIs those that have a resident board of executive directors, i.e., five out of 11 peers as per Table 1.1. Table 1.1 also suggests that resident boards often meet more than once a week, a far cry for the average of nine meetings/year one encounters in G-SIBs. 
The issue of effectiveness is even more acute with non-resident boards that retain significant authority over lending, such as the EIB board. It is virtually impossible for any part-time individual to approve a significant number of credit transactions. They will either not exercise enough diligence, or they will rely on a team of people, usually a team at the relevant ministry that oversees the institution and appoints its director. The latter approach, while probably sound from a control perspective, creates problems of personal engagement as discussed in the previous section. It results in directors becoming spokespersons of government teams rather than taking personal responsibility and fully engaging.

One effectiveness issue that is shared with private FIs is the use of committees to lighten the board's workload and allow it to focus more on strategic issue. ${ }^{45}$ Both private and international FIs sometimes struggle in making committees efficient and in using them as instruments of better time management rather than as additional workload. As Sir Adrian Cadbury noted "the purpose of committees is to make the board's work more manageable."46 The representative nature of IFI boards might, again, be a drag on effectiveness: member country representatives want (or are instructed) to be present in all committees, which in turn constitutes a double effectiveness "whammy" in some IFIs: committees are overcrowded, and the Board ends up duplicating committee discussions.

Having the right skills, knowledge, and experience is arguably even more critical on committees, which are usually tasked with hammering out difficult, complex issues and finding consensus before presenting recommendations to the whole board. But here again, committee membership is determined more by constituency representation than by expertise.

\subsection{Support}

The penultimate driver rests on a simple premise: a hard-working board needs good support by an effective team led by a senior member of management. It is now a well-accepted premise that effective boards need focused, senior support. The UK Corporate Governance Code clearly frames the issue:

Under the direction of the chairman, the company secretary's responsibilities include ensuring good information flows within the board and ties with private FIs, but it lies outside the scope of this brief paper. 
its committees and between senior management and non-executive directors, as well as facilitating induction and assisting with professional development as required. ${ }^{47}$

This is often an issue in private FIs where sometimes company secretaries are either too junior to convey the board's expectations to management or are too busy because they also have other important functions. From my experience these are not significant issues in IFIs which usually have dedicated functions led by senior members of management who have a high degree of institutional knowledge and expertise. ${ }^{48}$

Independence might however be an issue in IFIs - as is in those FIs that assign the secretariat function to senior managers such as the general counsel (a common occurrence in the US) or the CFO. The "classic" duty of company secretaries is to first and foremost serve the board. This is sometimes not easy to reconcile with the positioning of IFI company secretaries as senior management reporting to the President of the organization. Occasions might arise whereby the company secretary's "boss," i.e., the President, is challenged or "judged" by the board in which cases the company secretary might find themselves "in the middle."

\subsection{Maintenance}

Last but not least, boards need to regularly assess their effectiveness and ensure timely measures are taken to address any deficiencies. Board evaluations, either self-assessments or externally facilitated assessments, are a standard practice in private FIs. The evaluations contribute to maintaining an optimum level of effectiveness, particularly if there is a mechanism to follow up and implement recommendations targeted at improving effectiveness. All peers in the FI peer group had undertaken a board evaluation in 2015. ${ }^{49}$ Approximately 45 percent of these evaluations were facilitated by an outside consultant. ${ }^{50}$ Externally facilitated evaluations every few years are considered best practice

47 The UK Corporate Governance Code 2016, s B.5.

48 Another significant source of Board support in IFIs is the Evaluation Department, which, in most cases, is independent from Management, reports directly to the Board and has its own budget.

49 In Europe the annual evaluation of board effectiveness including the effectiveness of individual directors is a regulatory requirement. European Parliament and Council Directive 2013/36/EU art 97.4.

Nestor and Andersson (n 3$) 21$. 
and have been enshrined in several governance codes, including the UK Corporate Governance Code. ${ }^{51}$

In contrast, board evaluation has been a thorny issue for many IFI boards in the past. A 2015 IMF review of evaluation processes at the organization noted that, "Directors expressed skepticism about formal Board self-assessments [...] Some questioned the need for self-evaluation by the Board — and whether it is appropriate - given that Directors are accountable to country authorities. ${ }^{52}$

One of the outcomes of the 2009 Zedillo report is that the World Bank established an informal board of director self-evaluation mechanism in 2010 and is currently in the process of reviewing it, informing the review with current best practice in private FIs.

Two other IFI boards, AfDB and EIB appear to have conducted formal, board evaluations in recent years. At the AfDB, the executive board has conducted annual effectiveness reviews, which have been discussed at board meetings and board retreats; the outcome of these reviews seems to be an agenda/plan for improving board effectiveness. ${ }^{53}$ In 2014, the ЕІB undertook an externally facilitated board effectiveness assessment which looked critically at issues such as the time allocated by the board to discussing operational versus strategic matters, the need for adequate KSE, the performance of its Chairman, as well as the structure of committees, among other areas. Significantly, the externally facilitated assessment resulted in recommendations, some of which have been implemented but all of which were fully discussed by the board and implementation of the agreed recommendations is now part of the annual self-assessment of the board.

Other IFIs do not have proper board evaluation processes but have developed mechanisms to address board effectiveness. The EBRD seems to have gone once through an informal process involving a short questionnaire for board members. At the NIB, there is a board retreat on strategy every couple of years in which board effectiveness issues are also discussed. Another interesting practice at NIB is the development of a mechanism for each board member to self-reflect on areas on which they would benefit from training in the form of seminars or workshops. In this context, board members are asked to respond to a list of questions to probe to what extent board members feel comfortable

\footnotetext{
$5^{1} \quad$ UK Corporate Governance Code 2016 (n 45) s B.6.2.

$5^{2}$ Independent Evaluation Office of the International Monetary, Fund Self-Evaluation at the IMF: An IEO Assessment (IMF 2015) 21.

53 African Development Bank Group, African Development Bank Group Annual Report 2016 (AFDB Group 2017) <https://www.afdb.org/fileadmin/uploads/afdb/Documents/Gener icDocuments/AfDB_Annual_Report_2016_EN.pdf> accessed 17 January 2018.
} 
with certain issues and allows them to identify areas in which they may seek further training. ${ }^{54}$

\section{Conclusions}

Although this paper has called attention to some of the ways in which IFIs have sought to increase board effectiveness, it cannot offer detailed recommendations that would be fit for purpose for all IFIs. These can only be specific to each institution, its particular governance as "hard-wired" in its statutes and regulations, and its strategic objectives. It is however possible to identify four reform areas that, in the opinion of this author, appear to be "low-hanging fruits." The following are areas in which reforms can be implemented without challenging the fiendishly complex, politically sensitive packages of weighted voting, constituency design and board representation that often underpin IFI governance.

a. Allow board input in KSE and diversity - possibly by allowing the board to have an advisory voice on the matter.

b. Lengthen director tenure. In some cases, this will be difficult to do without challenging the hard-wiring of the particular IFI. There are however ways to throw institutional "sand" to slow rapid turnover momentum. For example, IFI governors could receive annual reports on board tenure and be encouraged to make statements of their intent to avoid replacing members before the end of their official tenure. Moreover, a reasoned decision/explanation could be required for all premature departures and a governor discussion scheduled for each such departure. Purely political motives could be discouraged. Also, the leadership of the IFI could initiate a discussion with constituencies on the merits and costs of short rotation spans for administrative purposes.

c. Find ways to allow for the participation of outsiders in board instances with no voting rights. This might be a way to address several issues ranging from institutional memory in short tenure boards to "missing" KSE in director populations to the "depoliticization" of certain sensitive topics.

d. Institutionalize a regular process of board self-evaluation and report key findings in annual reports.

I am quite confident that these changes would lead to effectiveness improvement. Nevertheless, one cannot not help but be a little cynical here. From one

54 Information in this area is mostly based on Nestor Advisors own experience and unofficial discussions with the management of some of the institutions. 
perspective, these changes are simple tinkering at the fringes of much bigger issues. There are two real "elephants in the room," and they are intimately related: the "dual" role of IF I directors - fiduciary and representative - and the way it ties into and feeds from the weighted voting structure, the constituency structure and the weak accountability of management; and the extensive retained authority of IFI boards which often perpetuates the institution of resident boards.

These elephants roam outside the perimeter of this paper but one can but marvel at their capacity to survive for so long, in some cases since the closing days of the Second World War, more than 70 years ago! 